\title{
TEACHERS PERCEPTION OF THE USE OF ICT AS AN INSTRUCTIONAL TOOL IN SCIENCE AND MATHEMATICS IN NIGERIA SECONDARY EDUCATION
}

\author{
*Ebire F. A.
}

*Department of Global ICT Policy, Pusan National University, Busan South Korea

*Email: francis.ebire@ pusan.ac.kr,francis.ebire@gmail.com

\begin{abstract}
The lagging performance of students in science and mathematics in West African Senior School Certificate Examination (WASSCE) points to a serious challenge requiring the intervention of the government, as we know; education is the bedrock of any nation. The application of ICT tools in teaching science and mathematics in Nigeria can be said to have minimally improved student performance in recent times. Though the government of Nigeria has made a laudable effort in these regards; it has little or no impact in teaching science and mathematics in Nigeria secondary education. Thus, this study aimed at examining the perception of teachers towards the use of ICT as an instructional tool in science and mathematics within Nigeria secondary education. The research employs a quantitative research design in which a sample of sixty-three (63) science and forty (40) mathematics teachers from government secondary schools in Abuja, Nigeria were interviewed. The instrument for data collection was a semi-structured questionnaire titled “Teacher's Perception on ICT Use Model (TPIUM)” based on the Technology Acceptance Model (TAM) by Davis, 1989. Statistical analysis of the data obtained showed that Perceived usefulness (PU) had the strongest impact on Behavioral intention (BI) and Attitude toward use (AT) of ICT tools by teachers. The findings of this study also revealed that outdated government policies to support ICT use in science and mathematics posed a big challenge and more consequential is the inadequate skills of teachers in using ICT tools. The study therefore recommends that the government should endeavor to put in place adequate training and retraining of teachers on how to effectively fuse and use ICT tools in teaching mathematics and other science subjects in Nigeria.
\end{abstract}

Keywords: ICT, Mathematics, Nigeria, Teachers, Science, Secondary Education

LICENSE: This work by Open Journals Nigeria is licensed and published under the Creative Commons Attribution License 4.0 International License, which permits unrestricted use, distribution, and reproduction in any medium, provided this article is duly cited.

COPYRIGHT: The Author(s) completely retain the copyright of this published article.

OPEN ACCESS: The Author(s) approves that this article remains permanently online in the open access (OA) mode.

QA: This Article is published in line with "COPE (Committee on Publication Ethics) and PIE (Publication Integrity \& Ethics)". 


\section{INTRODUCTION}

Education can be said to be the bedrock of both the developed and developing nations. Globally, most governments have devoted resources to information and communication technology (ICT) development, the traditional methods of instruction in Nigeria are been birthed out of academic and social impact due to the gradual introduction of ICT in learning (Arong and Ogbadu, 2010). The goal is to improve teaching and learning using innovative technologies in institutions of learning. This has brought about the formulation of Educational ICT policies; aimed at guiding the implementation processes of ICT use in schools (Awe, 2016).

Science instruction is basic requisite assuming a fundamental role in the innovative and technological improvement of a nation. Being aware of this, the federal government of Nigeria through the National Policy on Education maintained the compulsory learning of Mathematics in the primary and secondary levels of education. Owing to this, the government at all levels is making serious effort to provide high-quality Mathematics education. It is worthy of note that recognizable attempts, by various stakeholders, have been made in the past to enhance Mathematics teaching and learning and thereby making it more effective. Despite the important role played by science and mathematics education in the industrialization nation (Fakomogbon et al., 2014), there are several problems in improving science and mathematics education in Nigeria at the secondary level. The poor performance of students in science and mathematics final exams, such as WASSCE as reported by the Federal Ministry of Education (2018) goes to show a latent problem. The Senate president mandated a Committee on Education (Basic and Secondary) to meet with the minister of education and discuss the recurrent failure rate of students in a bid to finding a possible solution to improving the performance of the students. It's also highlighted in a research on student's performance in final examinations that there is a strong need to examine the cause of this decline performance (Utibe \& Agwagah, 2015). One major problem lies with how well teachers are able utilize ICT as an instructional tool in teaching. As Senator Biodun Olujimi in 2018 rightly pointed out; lots of teachers still have the phobia for ICT use in teaching science and mathematics, with very wrong perceptions on the use of ICT depending on how they perceive its usefulness or ease of use. Their level of education might also be a big hindrance to the proper use of these ICT tools as we have teachers who are not properly trained or lack basic and adequate skills to fully maximize and optimize these tools. Thus, it is important to explore how well the perception of teachers to ICT affects their teaching of science and mathematics, challenges faced and the benefits of ICT towards teaching sciences.

\section{RESEARCH OBJECTIVES}

The objectives of this study are outlined as follows:

- To evaluate the possible factors influencing in-service teachers' use of ICT in teaching science and mathematics in Nigeria secondary education

- To explore the possible challenges that affect the implementation of ICT tools in teaching science and mathematics in Nigeria secondary education

- To evaluate the level at which science and mathematics in-service teachers make use of ICT tools in Nigeria secondary education 


\section{RESEARCH HYPOTHESIS}

The proposed research hypothesis is based on the constructs of TAM (Technology Acceptance Model). The hypotheses exploits the relationships, significance, and influence each construct has on one another as using TAM (Davis, 1989).

\section{RESEARCH HYPOTHESIS}

\section{Hypothesis Statements:}

$\mathrm{H}_{1}$ : In-service teachers' attitudes towards use (AT) of ICT tools will be positively influenced by its perceived usefulness.

$\mathrm{H}_{2}$ : In-service teachers' attitudes towards use (AT) of ICT tools will be positively influenced by its perceived ease of use.

$\mathrm{H}_{3}$ : In-service teachers' perceived usefulness (PU) of ICT tools will be positively influenced by its perceived ease of use.

$\mathrm{H}_{4}$ : In-service teachers' behavioral intention (BI) to use ICT tools will be positively influenced by its perceived usefulness.

$\mathrm{H}_{5}$ : In-service teachers' behavioral intention (BI) to use ICT tools will be positively influenced by its attitude towards use.

\section{RESEARCH QUESTIONS}

This paper sought to answer the following research questions:

i. What are the factors that influence in-service teachers' intention to make use of ICT tools in teaching science and mathematics in the classroom?

ii. What are the challenges that affect the effective implementation of ICT tools in teaching and learning science and mathematics in Nigeria secondary education?

iii. How well do science and mathematics in-service teachers use ICT tools in Nigeria secondary education?

\section{METHODOLOGY}

The study employed a quantitative research design in which a sample of sixty-three (63) science and forty (40) mathematics teachers from government secondary schools in Abuja, Nigeria were interviewed. The instrument for data collection was a semi-structured questionnaire titled "Teacher's Perception on ICT Use Model (TPIUM)" based on the Technology Acceptance Model (TAM) by Davis, 1989. The target population for the study are in-service teachers in government secondary schools in Abuja. One hundred and twenty (120) questionnaires were administered to seventy-five (75) science and forty-five (45) mathematics teachers. The disparity in the number of sciences to mathematics teachers was due to the available number of volunteers for the study. Incomplete responses were discarded; leaving one hundred and three (103) that was completed in total i.e. $97 \%$ of the question administer was completed and used for data analysis (Gay, Miles and Airasian, 2012). 
The two main constructs upon which the study model was built are Perceived usefulness and Perceived ease of use (Alharbi and- Drew, 2014).

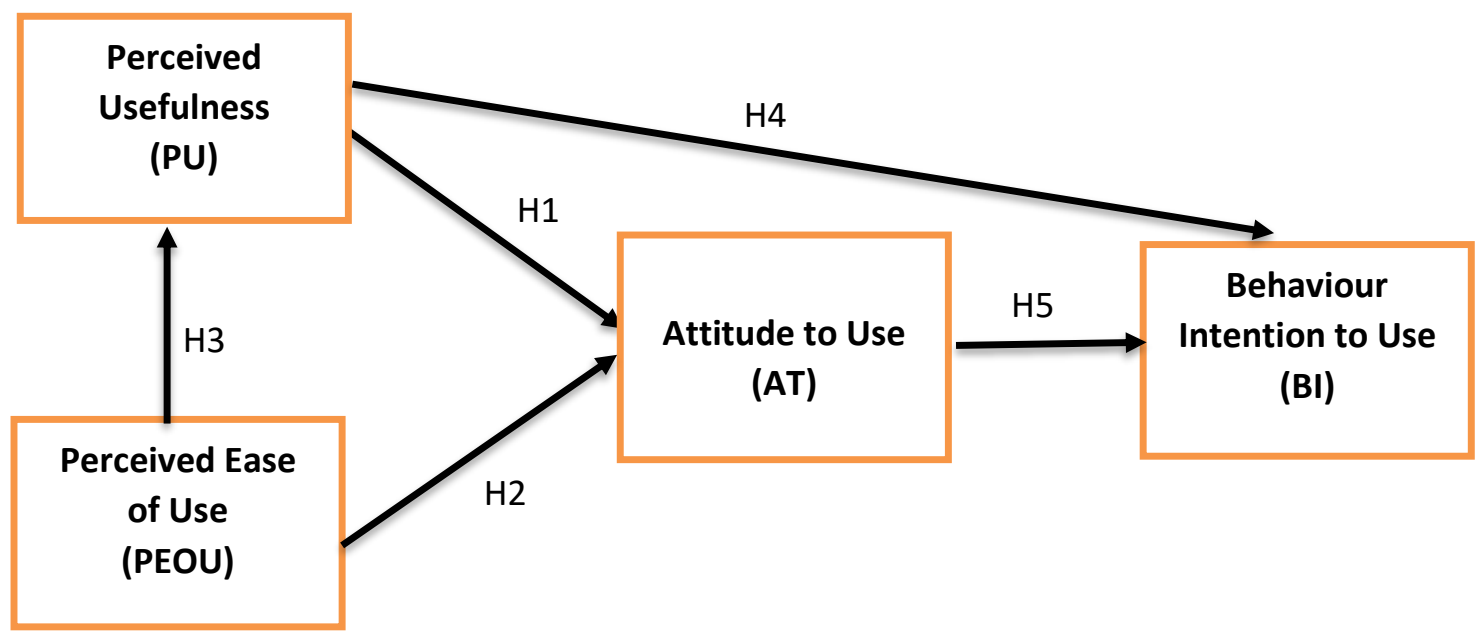

Figure 1: Demonstrate TAM model and the relationships between the different variables

Proposed Teacher's Perception of ICT Use Model (TPIUM) based on the Technology Acceptance Model (TAM) (Davis, Fred D, 1989).

- Perceived Usefulness (PU): This can be defined as the extent to which an individual trust that using a specific system would enrich his or her performance at a given time or job.

- Perceived Ease of Use (PEOU): This can be said to be the level or extent to which an individual sees or trust that using a specific system would not be tedious and free of stress.

\section{DATA COLLECTION}

The instrument for the data collection is a semi-structured questionnaire titled "Teacher's Perception of ICT Use Model (TPIUM)". It was marginally altered by the analyst and titled "Teachers Perception on the Utilization of ICT as an Instructional Tool in Science and Mathematics" focusing on in-service science and mathematics teachers.

The TAM-questionnaire consists of a five-point Likert scale ranging from "strongly agree" to "strongly disagree" with a not applicable option. Teachers were given statements and asked to rate this using 5-point Likert which ranges from Strongly Agree (SA), Agree (A), Neutral (N), Disagree (D), Strongly Disagree (SD).

\section{CORRELATION ANALYSIS}

After conducting the Reliability Analysis, the correlation coefficients were inspected in order to ascertain the relationships between four (4) factors. This was paramount in testing the hypotheses of the research model. The statistical analysis tool used for the analysis was IBM SPSS Statistics Base 22.0. 


\section{RESULTS}

Table 1: Correlation between PEOU, PU, AT and BI

\begin{tabular}{|c|c|c|c|c|c|}
\hline & Factor & PEOU & PU & $\mathbf{A T}$ & BI \\
\hline PEOU & Pearson Correlation & 1 & $0.529 * *$ & $0.647 * *$ & $0.495 * *$ \\
\hline PU & Pearson Correlation & $0.529 * *$ & 1 & $0.727 * *$ & $0.765 * *$ \\
\hline AT & Pearson Correlation & $0.647 * *$ & $0.727^{* *}$ & 1 & 692 \\
\hline BI & Pearson Correlation & $0.495^{* *}$ & $0.765^{* *}$ & $0.692 * *$ & 1 \\
\hline
\end{tabular}

The table above shows that the correlations between the PEOU, PU, AT and BI the positivity and significance level are high. This also confirms the original hypothesis for this study and the influence of different factors on the use of ICT.

\section{HYPOTHESES TESTING}

In testing the theories, the aim was to ascertain which indicators (independent variables) give an important contribution to the clarification of the reliant factors. To additionally test this hypothesis, a regression analysis was conducted to test the $\mathrm{H} 1$ and $\mathrm{H} 2$.

Table 3a: Independent Variables or Predictors: PU \& PEOU $\longrightarrow$ Dependent Variable: AT (Model Summary)

\begin{tabular}{lllll} 
Model & $\mathbf{R}$ & R Square & Adjusted R Square & Std. The error of the Estimate \\
\hline 1 & $.783^{\mathrm{a}}$ & .613 & .609 & .50840
\end{tabular}

a. Predictors: (Constant), PU, PEU 
Table 3b: Independent Variables or Predictors: PU \& PEOU $\longrightarrow$ Dependent Variable: AT (Coefficients)

\begin{tabular}{|c|c|c|c|c|c|c|}
\hline \multirow[b]{2}{*}{ Model } & & \multicolumn{2}{|c|}{ Unstandardized Coefficients } & $\begin{array}{l}\text { Standardized } \\
\text { Coefficients }\end{array}$ & \multirow[b]{2}{*}{$\mathbf{T}$} & \multirow[b]{2}{*}{ Sig. } \\
\hline & & B & Std. Error & Beta & & \\
\hline 1 & (Constant) & .284 & .187 & & 1.519 & .130 \\
\hline & PEOU & .327 & .048 & .346 & 6.763 & .005 \\
\hline & PU & .595 & .056 & .540 & 10.542 & .000 \\
\hline
\end{tabular}

As shown in Table 3a, the estimation of R square shows that the two indicators (PU, PEOU) showed 61.3\% of the variety in Attitudes to utilize. This implies that this model is judicious, even though other obscure variables may influence the in-service teacher's attitude to utilize ICT tools that are excluded in this model. The standardized coefficients $(\beta)$ which examined the quality of the impact of every independent variable to the dependent variable demonstrates that Perceived Usefulness $(\beta=0.540)$ have a bigger effect than the Perceived Ease of Use $(\beta=0.346)$, which implies that the impression of value in-service teachers have about the utilization of ICT devices influence their perception to utilize ICT tools in teaching science and mathematics in Nigeria secondary education. Furthermore, the Sig (significance) shows that both of the indicators had a huge and positive effect on AT scores at the 0.001 level.

Also, a linear regression model was additionally used to test $\mathrm{H} 4$ and $\mathrm{H} 5$, which are the effect of Perceived Usefulness and Attitude on in-service teacher's attitudes to utilize ICT tools in teaching science and mathematics in Nigeria secondary education.

Table 4a: Independent Variables or Predictors: PU \& AT $\longrightarrow$ Dependent Variable: BI (Model Summary)

\begin{tabular}{|c|c|c|c|c|}
\hline Model & $\mathbf{R}$ & R Square & $\begin{array}{l}\text { Adjusted } \\
\text { Square }\end{array}$ & $\begin{array}{l}\text { R Std. The error of } \\
\text { the Estimate }\end{array}$ \\
\hline 1 & $.789^{\mathrm{a}}$ & .623 & .619 & .49837 \\
\hline
\end{tabular}

Table 4b: Independent Variables or Predictors: PU \& AT $\longrightarrow$ Dependent Variable: BI (Coefficients)

\begin{tabular}{|c|c|c|c|c|c|c|c|}
\hline \multirow[b]{3}{*}{ Model } & & \multirow{2}{*}{\multicolumn{2}{|c|}{ Unstandardized Coefficients }} & \multirow{2}{*}{$\begin{array}{l}\text { Standardized } \\
\text { Coefficients }\end{array}$} & \multirow[b]{3}{*}{$\mathbf{T}$} & \multirow[b]{3}{*}{ Sig. } & \\
\hline & & & & & & & \\
\hline & & B & Std. Error & Beta & & & \\
\hline 1 & (Constant) & .313 & .178 & & 1.755 & .081 & \\
\hline & PU & .605 & .068 & .553 & 6.931 & .000 & \\
\hline & AT & .288 & .062 & .290 & 4.673 & .000 & \\
\hline a. & & Dependent & & Variable: & & & $\mathrm{BI}$ \\
\hline
\end{tabular}


As observed in table $4 \mathrm{a}$, the value of $\mathrm{R}$ square indicates that the two predictors (PU, PEOU), showed $62.3 \%$ of the variation in behavioral intention to use. It also shows that the model is rational. The standardized coefficients( $\beta)$ which compare the strength of the effect of each independent variable to the dependent variable shows that Perceived Usefulness $(\beta=0.553)$ have a larger impact than the Attitude to use information communication technology tools in teaching science and mathematics $(\beta=0.290), \mathrm{Sig}=0$. Also, it confirmed that Perceived Usefulness (PU) H4 had a significant effect on Behavioral Intention (BI), with $\beta=0.553$, Sig $=0$. While Attitude toward (AT) had a positive influence on dependent variable BI, with $\beta=0.290$, Sig $=0$.

Table 5a: Independent Variables or Predictors: PEOU $\longrightarrow$ Dependent Variable: PU (Model Summary)

\begin{tabular}{llllll}
\hline & & & Adjusted & R & Std. Error of the \\
Model & $\mathbf{R}$ & R Square & Square & Estimate \\
\hline 1 & $.539^{\text {a }}$ & .291 & .287 & .62348 \\
\hline \multicolumn{5}{c}{ a. Predictors: (Constant), PEOU }
\end{tabular}

Table 5a: Independent Variables or Predictors: PEOU $\rightarrow$ Dependent Variable: PU (Coefficients)

\begin{tabular}{|c|c|c|c|c|c|c|}
\hline & & & & Standardizec & & \\
\hline & & Unsta & d Coefficients & Coefficients & & \\
\hline Model & & B & Std. Error & Beta & $\mathbf{T}$ & Sig. \\
\hline 1 & (Constant) & 1.985 & .184 & & 10.807 & .000 \\
\hline & PEOU & .462 & .050 & .539 & 9.251 & .000 \\
\hline
\end{tabular}

As seen in table 5a, the R Square value (0.291) is low, thus indicating that PEOU showed only $29.1 \%$ of the variation in PU. Based on Standardized coefficient value $(\beta=0.539)$, Perceived Ease of Use (PEOU) had a significant impact on Perceived Usefulness (PU). 
Table 6: Summary of Model Hypothesis

\begin{tabular}{|c|c|c|}
\hline $\begin{array}{l}\text { Hypothesis } \\
\text { Results }\end{array}$ & Effect / Specification & Result \\
\hline $\mathbf{H}_{1}$ & $\begin{array}{l}\text { In-service teachers' attitudes towards use (AT) of ICT tools will be } \\
\text { positively influenced by its perceived usefulness. }\end{array}$ & $\begin{array}{l}\text { Supported }(\beta=0.547 \\
\mathrm{p}<0.001)\end{array}$ \\
\hline $\mathbf{H}_{2}$ & $\begin{array}{l}\text { In-service teachers' attitudes towards use (AT) of ICT tools will be } \\
\text { positively influenced by its perceived ease of use. }\end{array}$ & $\begin{array}{l}\text { Supported }(\beta=0.362, \\
\mathrm{p}<0.001)\end{array}$ \\
\hline $\mathbf{H}_{3}$ & $\begin{array}{l}\text { In-service teachers' perceived usefulness (PU) of ICT tools will be } \\
\text { positively influenced by its perceived ease of use. }\end{array}$ & $\begin{array}{l}\text { Supported }(\beta=0.548, \\
\mathrm{p}<0.001)\end{array}$ \\
\hline $\mathbf{H}_{4}$ & $\begin{array}{l}\text { In-service teachers' behavioral intention (BI) to use ICT tools will be } \\
\text { positively influenced by its perceived usefulness. }\end{array}$ & $\begin{array}{l}\text { Supported }(\beta=0.561 \text {, } \\
\mathrm{p}<0.001)\end{array}$ \\
\hline $\mathbf{H}_{5}$ & $\begin{array}{l}\text { In-service teachers' behavioral intention (BI) to use ICT tools will be } \\
\text { positively influenced by its attitude towards use. }\end{array}$ & $\begin{array}{l}\text { Supported }(\beta=0.295 \text {, } \\
\mathrm{p}<0.001)\end{array}$ \\
\hline
\end{tabular}

LINEAR

REGRESSION

MODEL

RESULT

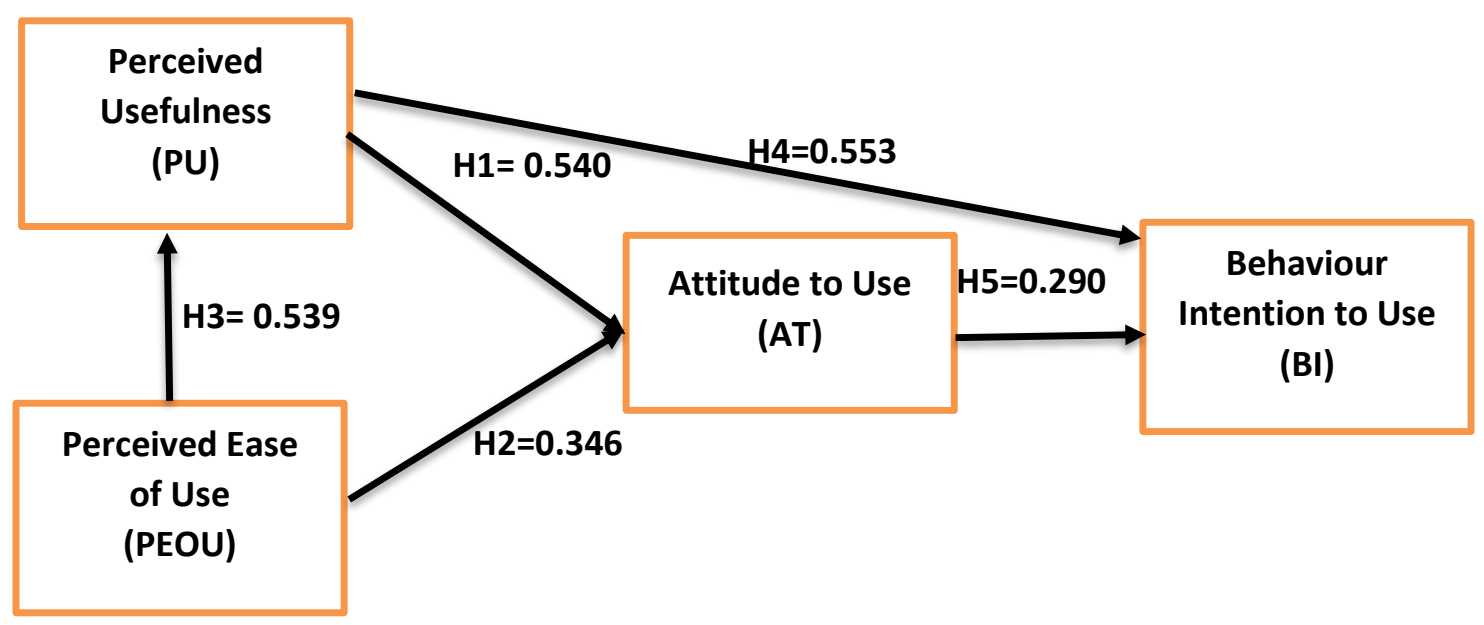

Figure 2: Linear regression model result

\section{HYPOTHESIS TESTING USING THE RESEARCH MODEL RESULTS:}

\section{H1: Perceived usefulness (PU) -- Attitude Towards Use (PU $\rightarrow$ AT)}

The result of the hypothesis testing showed that Perceived usefulness positively affects influence in-service teachers' attitudes towards the use of Information communication technology tools $(\beta=0.54, p<0.001)$. Therefore, H1 is supported. 


\section{H2: Perceived ease of Use (PEOU) -- Attitude Towards Use (PEOU $\rightarrow$ AT)}

It was theorized that perceived ease of use will have a significant impact on in-service teachers' attitudes to use ICT tools. In this study, perceived ease of use positively influences in-service teacher's attitudes towards the use of ICT tools $(\beta=0.346, \mathrm{p}<0.001)$. Therefore, $\mathrm{H} 2$ is supported.

\section{H3: Perceived Ease of Use (PEOU) -- Perceived Usefulness (PEOU $\rightarrow$ PU)}

Theories in this research show that perceived ease of use will have a significant impact on in-service teachers' perceived usefulness of ICT tools $(\beta=0.539, \mathrm{p}<0.001)$. Therefore, H3 is supported.

\section{H4: Perceived Ease of Use (PU) -- Behavioral Intention (PU $\rightarrow$ BI)}

It was theorized that perceived usefulness will positively influence in-service teachers' behavioral intention to use ICT tools. In this study, perceived usefulness positively influences in-service teacher's behavioral intention ( $\beta=0.553$, $\mathrm{p}<0.001)$. Thus, $\mathrm{H} 4$ is supported.

\section{H5: Attitude to use (AT) - Behavioral Intention (AT $\rightarrow$ BI)}

Theories in this research show that attitude to use ICT tools will positively influence in-service teachers' behavioral intention to use ICT tools $(\beta=0.29, \mathrm{p}<0.001)$. Therefore, H5 is supported. 
Table 7: Challenges of implementing ICT tools in teaching and learning of science and mathematics

\begin{tabular}{|c|c|c|c|c|c|c|c|c|}
\hline \multirow[b]{2}{*}{ No } & \multirow[b]{2}{*}{ Questions } & \multicolumn{5}{|c|}{ Response Percentage ( $\mathrm{N}=103)$} & \multirow[b]{2}{*}{ Mean } & \multirow[b]{2}{*}{ SD } \\
\hline & & $\begin{array}{l}\text { Strongly } \\
\text { Agree }\end{array}$ & Agree & $\begin{array}{l}\text { Neutra } \\
1\end{array}$ & Disagree & $\begin{array}{l}\text { Strongly } \\
\text { Disagree }\end{array}$ & & \\
\hline 1 & $\begin{array}{l}\text { Outdated } \\
\text { Government policy } \\
\text { to support ICT use in } \\
\text { science } \\
\text { mathematics and }\end{array}$ & 73.4 & 20.2 & 1.5 & 1.8 & 3.0 & 4.59 & .853 \\
\hline 2 & $\begin{array}{l}\text { No adequate skills of } \\
\text { teachers for using } \\
\text { ICT }\end{array}$ & 48.3 & 32.6 & 13.6 & 3.9 & 1.5 & 4.07 & .868 \\
\hline 3 & $\begin{array}{lrr}\text { Teachers } & \text { training } \\
\text { about how } & \text { to } \\
\text { integrate ICT } & \text { in } \\
\text { science } & \text { and } \\
\text { mathematics } & \\
\text { teaching } & \end{array}$ & 65.9 & 23.0 & 3.3 & 5.1 & 2.7 & 4.44 & .975 \\
\hline 4 & $\begin{array}{l}\text { Pedagogical models } \\
\text { on how to use ICT } \\
\text { for teaching and } \\
\text { learning science and } \\
\text { mathematics }\end{array}$ & 55.6 & 26.9 & 6.3 & 7.6 & 3.6 & 4.23 & 0.981 \\
\hline 5 & $\begin{array}{l}\text { Insufficient number } \\
\text { of ICT devices }\end{array}$ & 4.2 & 12.1 & 17.2 & 33.8 & 32.6 & 2.21 & .956 \\
\hline 6 & $\begin{array}{l}\text { School time } \\
\text { organization (fixed } \\
\text { lesson time, etc.) }\end{array}$ & 22.1 & 36.6 & 15.7 & 21.1 & 4.5 & 3.50 & 1.171 \\
\hline & Total & - & - & - & - & - & 3.84 & 0.961 \\
\hline
\end{tabular}

Table 7 shows the results obtained on the challenges of implementing ICT tools in teaching and learning of science and mathematics. The teacher's response was rated on a Likert scale of 1-5, from 'Strongly Agree' (1) to 'Strong Disagree' (5). 
Table 8: Teachers ICT Usage

\section{Response Percentage $(\mathrm{N}=103)$}

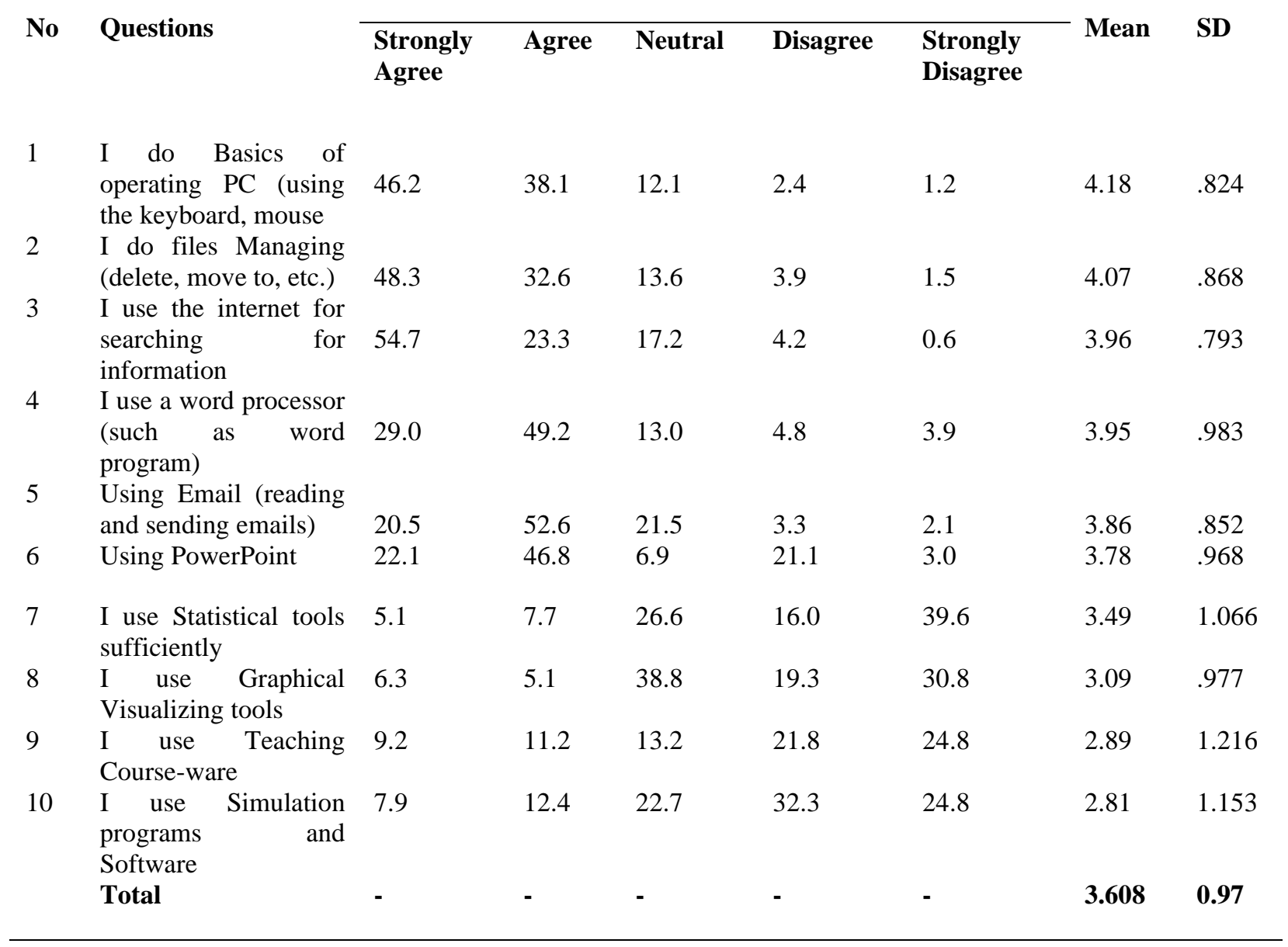

Table 8 shows the results obtained on how science and mathematics teachers use ICT tools. The teacher's response was rated on a Likert scale of 1-5, from 'Strongly Agree' (1) to 'Strong Disagree' (5).

\section{DISCUSSION}

This section examines the results obtained from the instruments used for this study with emphasis on the research questions and, utilizes evidence from the quantitative aspects of the analysis previously done.

Research Question 1: What are the factors that have influence science and mathematics in-service teachers' intention to make use of ICT in the classroom?

It can be deduced from the analyzed result that Perceived Usefulness (PU) had the strongest impact on Behavioral Intention (BI), followed by the influence of Perceived Usefulness (PU) on Attitude toward (AT). In-service teachers will be willing to adopt or use technology or ICT tools that are relevant, useful and will help them teach science and 
mathematics better, and with tangible evidence of results. Those are strong and enduring reasons for technology to be favored and utilized (Al-Busaidi \& Al-Shihi, 2010).

Perceived Ease of Use (PEOU) also had a positive impact on in-service teachers' Attitude toward (AT) using ICT, although the magnitude of its influence was moderate, this was also emphasized by Jeffrey (2015) in his research on testing the impact of the technology acceptance model. He described that willingness to adopt a new behavior or innovation and attitude to use this is influenced by the technicality and complexity of the technology which can be said to be the ease of use.

Research Question 2: What possible challenges affect the effective implementation of ICT tools in teaching and learning science and mathematics in Nigeria secondary education?

It can be deduced from the analysis done that entire disclosures mean showed a high level, it can be said that the highest challenge teachers highlighted are Outdated Government policy to support ICT use in science and mathematics with ( $\mathrm{M}=4.59, \mathrm{SD}=.853)$. This can also be proved or emphasized from the study of pre-service teachers' perception of ICT integration which highlighted policy as the major barrier been faced (Redmond and Albion, 2014). The teachers also highlighted inadequate skills for using ICT tools as another top challenge $(\mathrm{M}=4.04 \mathrm{SD}=.868)$ which hinders the effective use of ICT. Teacher knowledge of ICT tools is moderate but most of them lack the related ICT skills or training program to develop and improve their competencies in ICT use (Baya'a \& Daher, 2013). Other challenges, which are highlighted, are lack of teachers training on how to integrate ICT into science and mathematics and lack of pedagogical model in teaching science and mathematics in Nigeria.

Research Question 3: How well do science and mathematics in-service teachers use ICT tools in Nigeria secondary education?

This is not the main question but a sub-question, in which the intention is to investigate how well science and mathematics teachers in Nigeria use ICT tools. It could be deduced that some teachers have a basic knowledge of the use of ICT tools such as using the mouse, keyboard, file management, internet surfing and this can be a good basis for improvement when it comes to training and skill development since they are not strange to the use of these tools. However, the overall use of ICT tools by science and mathematics teachers in Nigeria secondary education is moderate though, with little or no integration in teaching science and mathematics.

\section{CONCLUSIONS}

The result of this study showed that Perceived usefulness (PU) had the strongest impact on Behavioral Intention (BI), followed by Attitude toward (AT) using ICT tools in teaching science and mathematics in by in-service teachers in Nigeria secondary education. The Perceived Ease of Use (PEOU) is also a factor, which had an impact on in-service teachers Attitude toward (AT) using ICT tools, but this is at a moderate level compared to the impact of perceived usefulness. Also, one of the greatest challenges teachers highlighted as a major barrier to implementing ICT use in 
teaching science and mathematics is an outdated government policy to support ICT use. This challenge is critical and the skills of teachers in using ICT tools is quite low.

\section{RECOMMENDATION}

In an attempt to tackle these issues, the study therefore proffers the following recommendations:

- The Government of Nigeria should ensure collaborative working between the ministry of education and the ICT ministry in ensuring the effectively integration of ICT in science and mathematics curriculum.

- The use of ICT resources should be strongly advocated, teachers should be shown how to benefit from this and how-to best use information technology to enhance the educational process. However, the technophobic tendencies of some teachers should be kept in mind.

- The Government of Nigeria through the Ministries of Education and ICT should ensure that all teachers receive adequate in-depth training and re-training with methods on how to effectively integrate ICT into the teaching and learning of science and mathematics in Nigeria education.

- The study acknowledge that ICT is been taught as a separate subject, policymakers should put ICT at the center of all subjects, not just science and mathematics alone.

- Policymakers in the Government of Nigeria should modify and improve existing Pedagogical models learning from South Korea and South Africa's case on how to use ICT for teaching and learning science and mathematics.

\section{LIMITATION OF STUDY}

This study only examined the factors affecting the perception of in-service teachers towards the use of ICT tools in teaching science and mathematics in government secondary schools in Abuja, the capital city of Nigeria. The results may not be generalized to other parts of the country and other developing countries. Also, the sample is limited to secondary school in-service teachers whose specialty is science and mathematics. Therefore, utilizing this research model for future research work, will validate the model and its findings in other developing countries.

\section{ACKNOWLEDGMENTS}

Special thanks to Nigeria and Korea Government, KOICA and my advisors (Prof. Kim Youngmin, Prof. Park So-hwa, and Prof. Sang-mi Kim). 


\section{REFERENCES}

Al-Busaidi, K. A. and Al-Shihi, H. (2010). A Framework for Evaluating Instructors' Acceptance of Learning Management Systems. Knowledge Management and Innovation in Advancing Economies-Analyses \& Solutions, Vols 1-3, 2010, 1199-1207. https://doi.org/10.5171/2010.862128

Alharbi, S. and Drew, S. (2014). Using the Technology Acceptance Model in Understanding Academics' Behavioural Intention to Use Learning Management Systems. International Journal of Advanced Computer Science and Applications, 5(1), 31-56. https://doi.org/10.14569/IJACSA.2014.050120

Arong, F. E. and Ogbadu, M. A. (2010). Major Causes of Declining Quality of Education in Nigeria from Administrative Perspective : A Case Study of Dekina Local Government Area. Canadian Social Science, 6(3), 183-198.

Awe, O. O. (2016). ICT4D Strategic Action Plan Implementation: Status Update and illustrations Book.

Baya'a, N. and Daher, W. (2013). Mathematics teachers' readiness to integrate ICT in the classroom. International Journal of Emerging Technologies in Learning, 8(1), 46-52. https://doi.org/10.3991/ijet.v8i1.2386

Davis, Fred D. R. B. (1989). User Acceptance of Computer Technology : A Comparison of Two Theoretical Models User Acceptance Of Computer Technology: A Comparison Of Two. September 2016. https://doi.org/10.1287/mnsc.35.8.982

Davis, F. D. (1989). Perceived Usefulness, Perceived Ease of Use, and User Acceptance of Information Technology. MIS Quarterly, 13(3), 319-340. https://doi.org/10.2307/249008

Fakomogbon, M. A., Adebayo, R. F., Adegbija, M. V., Shittu, A. T. and Oyelekan, O. S. (2014). Subject Specialization and Science Teachers' Perception of Information and Communication Technology for Instruction in Kwara State. International Journal of Information and Communication Technology Education, 10(1), 25-34. https://doi.org/10.4018/ijicte.2014010103

Jeffrey, D. A. (2015). Testing the Technology Acceptance Model 3 (TAM 3) with the Inclusion of Change Fatigue and Overload, in the Context of Faculty from Seventh-day Adventist Universities: A Revised Model. Dissertations, 3(Paper 1581), 166. http://digitalcommons.andrews.edu/dissertations

Gay, L.R, \& Miles, G. E., and Airasian, P. (2012). Educational research: Competencies for analysis and applications (10 ${ }^{\text {th }}$ ed, pp 25-27). Boston: Pearson Education International.

Redmond, P. and Albion, P. R. (2014). In their own words: Pre-service teachers' perceptions of ICT integration. Society for Information Technology \& Teacher Education 13th International Conference, May 2426-2430.

Utibe, U. J. and Agwagah, U. N. (2015). A Decade of Candidates' Performances in NECO-SSCE Mathematics in Nigeria. Journal of Education and Practice, 6(25), 25-30. 